\title{
The Latin American Indigenous Ethnopolitics: Toward an Expansive and Comprehensive Climate Governance
}

\author{
Luciano Alberto Ferreira $^{1 *}{ }^{(0)}$, Vladimir Passos de Freitas ${ }^{1}\left(\mathbb{D}\right.$, Gilberto Passos de Freitas $^{2}$ \\ ${ }^{1}$ School of Law, Pontifical Catholic University of Paraná, Curitiba, Brazil \\ ${ }^{2}$ School of Law, Catholic University of Santos, Santos, Brazil \\ Email: *luciano.alberto@pucpr.edu.br, vladimir.passos@pucpr.br, gpassosfreitas@uol.com.br
}

How to cite this paper: Ferreira, L. A., de Freitas, V. P., \& de Freitas, G. P. (2021). The Latin American Indigenous Ethnopolitics: Toward an Expansive and Comprehensive Climate Governance. Beijing Law Review, 12, 447-462.

https://doi.org/10.4236/blr.2021.122025

Received: March 29, 2021

Accepted: May 5, 2021

Published: May 8, 2021

Copyright $\odot 2021$ by author(s) and Scientific Research Publishing Inc. This work is licensed under the Creative Commons Attribution International License (CC BY 4.0).

http://creativecommons.org/licenses/by/4.0/

\begin{abstract}
Discussions about climate governance and climate justice from an international perspective have highlighted a close relationship between climate change and human rights. Thereafter the number of national and international policies and litigation about this relationship has increased worldwide, according to recent researches. Furthermore, indigenous claims and actions about this relationship have risen before public spheres at all climate governance levels by taking ethnopolitics paths. Through a hypothetical-deductive approach and bibliographic and documentary research, this study aims to address these paths grounded in a South Global perspective from Latin American indigenous people's claims and actions on collective human rights before climate changes. It is assumed that those ethnopolitics paths have contributed to an expansive and comprehensive formulation of climate governance. The findings indicate that besides the increase's trends of national's laws and policies and litigation before national and international courts, the indigenous people's ethnopolitical protagonism related to their claims on collective human rights before climate changes in Latin American has updated the formulation of climate governance toward climate justice by an expansive and comprehensive approach, embracing political protagonism grounded in ethnics and its cultural aspects, taking into traditional ways of life vitally dependent on a balanced ecological system, and problematizing states and hegemonic societies' mechanisms to face climate change from a multicultural perspective.
\end{abstract}

\section{Keywords}

Climate Change, Climate Governance, Climate Justice, Ethnopolitic, Indigenous People 


\section{Introduction}

Extremes weather events as such droughts, floods, hurricanes, and so on, boosted by climate change, is leading us to a growing human right crisis, especially bearing in mind the disproportionate climate changes' adverse effects among different peoples around the world. Thus, some recent discussions about climate justice and climate governance have highlighted a close relationship between climate change and human rights from an international perspective.

Thereafter a development of national and international policies and litigation about this relationship has been increased worldwide. Besides, the Latin American indigenous claims about this matter have also been raised before public spheres at all levels of climate governance by taking ethnopolitics paths, which could be identified as an expansive and comprehensive approach to climate governance and climate justice.

Climate justice goes about fulfilling human rights by identifying both rightsholders and duty-bearers before the injustice related to those who disproportionately undergo the direct and indirect negative impacts of climate change (United Nations Framework Convention on Climate Change, 1997; Olawuyi, 2015; OHCHR, 2020; Calañas \& Urbinati, 2020). Climate governance comprises tools to enhance actions that authoritatively steer constituents towards social justice before climate changes through diverse actors from business, local government, and civil society (Setzer \& Byrnes, 2020; Andonova, Betsill \& Bulkeley, 2009; Jordan, Huitema, Hildén et al., 2015).

In this sense, through a hypothetical-deductive approach and bibliographic and documentary research, this study aims to address climate governance toward climate justice grounded in a South Global perspective regarding Latin American indigenous peoples' claims.

\section{Human Rights and the Pursuit of Climate Justice}

The concept of climate justice, relating global warming or climate changes to human rights, becomes a top priority to face the actual human rights crisis, mainly related to inequality and its root causes, according to United Nations Human Rights Council (2008, 2009, 2016), Calañas \& Urbinati (2020), OHCHR (2020), Expert Group on Global Climate Obligations (2015), Expert Group on Climate Obligations Of Enterprises (2018), Sustainable Development Goals (2020), and Olawuyi (2015).

An early principle of climate justice was about countries' equality on environment and development rights by the United Nations Conference on Environment and Development, 1992, known as ECO-92 or The Earth Summit. The primary outcome for this conference, the Rio Declaration, adopted principle 6 . Through this principle, the unique "situation and needs of developing countries," especially "the least developed and those environmentally vulnerable," demand priority," in a manner that actions in the international level about environment and development should be addressed by "the interests and needs of all 
countries." (United Nations, 1992: p. 2). This principle highlighted the relationships between national states on equality.

In 2007 a significant milestone to address climate change in relationship with human rights at the international level beyond countries' equality took place: The Male Declaration on the Human Dimension of Global Climate Change. This first intergovernmental statement explicitly recognized that climate change has obvious and immediate implications for the "full enjoyment of human rights" by the people (Center for International Environmental Law, 2007).

Through this declaration was requested to the Human Rights Council (HRC) to summon a debate on human rights and climate change to the Office of the United Nations High Commissioner for Human Rights (OHCHR) an study about the effects of climate change on the enjoyment of human rights, and to the Conference of the Parties to pursue cooperation toward assessing the human rights implications of climate change (United Nations Human Rights Council, 2016).

In 2008, the Human Rights Council (HRC) adopted Resolution 7/23, which gave impetus for The Office of the United Nations High Commissioner for $\mathrm{Hu}-$ man Rights (OHCHR) to issue the 2009 report, explaining the relationship between climate change and human rights. This report cleared that national states have duties to protect their people against any human rights threats from the effects of climate change. Since then, the international discourse on the relationship between climate change and human rights evolved to ground international climate change agreement frameworks as can be observed, for example, from the Cancún Agreements at the 16th Conference of Parties (COP) and the Decision 1/CP.21, adopted by Paris Agreement at the 21st COP, wherein both lay down recognizing human rights principles, setting precedents in following international climate change agreements (United Nations Human Rights Council, 2008; United Nations Human Rights Council, 2009; Calañas \& Urbinati, 2020).

Thereby, a common international understanding about the direct adverse effects of climate change on human rights raised. In this sense, the impact of climate change, like stronger coastal storms, prolonged droughts, and other weather events, is considered to cause water-borne diseases, respiratory diseases, malnutrition, and heat strokes, to mention a few. Thus, according to the UN, this scenario is reportedly on the rise as more and more populations are exposed to extreme weather events. Hence, those international agreements contributed to institutionalizing "the role of duty bearers-primarily the national state-in taking effective measures to prevent, redress, mitigate, and adapt to the changing climate" besides other duty bearers obligations of the enterprises about emissions production (Calañas \& Urbinati, 2020: p. 2).

Whence, a human rights-based approach (HRBA) has raised at the international level to promotes and protects human rights, by including the fulfillment of human rights as an overall objective, the identification of "both rights-holders and duty-bearers (the former's entitlement and the latter's obligations)," and 
clarifying ways to operationalization those principles and standards grounded on international human rights law (OHCHR, 2020).

Since then, scholars have elaborated this approach to identify and address the root causes of inequalities, social exclusions, and human rights violations that could disturb development programs and policies' efficacies (Olawuyi, 2015). The support for adopting an HRBA has been solidified over the years. Human rights jurists and advocates reverberate these calls, primarily through the Oslo Principles on Global Climate Change Obligations and the states' legal obligations according to areas of international law (Expert Group on Global Climate Obligations, 2015; Expert Group on Climate Obligations of Enterprises, 2018; Sustainable Development Goals, 2020). So, by HBRA, carried out inter alia by human rights scholars and practitioners, Civil Society Organizations (CSOs) initially, those situated in the Global North-and UNFCCC, the notions about the relationship between human rights and climate change have shaped the climate justice movement.

Another well-known approach to climate justice is the "common but differentiated responsibility principle" (CBDR principle), grounded in the Kyoto Protocol, Article 10. According to this international legal provision, all the countries should consider their "common but differentiated responsibilities" according to their specific national and regional development priorities, besides their objectives and circumstances (United Nations Framework Convention on Climate Change, 1997). Regarding the CBDR principle, climate justice may be associated with two crucial broader critical issues.

The first one goes about the injustice related to "the most vulnerable who bear a disproportionate burden from" the direct negative impacts of climate change due to poverty, extreme weather events, energy insecurity, and the increasing world's water and food scarcity. It demands an international legal framework that should address the climate change effects and "the disproportionate burden placed on poor and small island states." (United Nations Framework Convention on Climate Change, 1997: pp. 3-4; Olawuyi, 2015: p. 106). This approach of climate justice grounds on the "proposals to include funding and compensation mechanisms as parts of the international climate change regime to ensure global burden-sharing in combating climate change" (Olawuyi, 2015: p. 106; Calañas \& Urbinati, 2020).

The second broader key issue on climate justice according to the CBDR approach is related to those research findings that pointed how the policy measures and projects destined to mitigate climate change, especially in developing countries, could seriously threaten human rights by indirect negative impacts. These impacts could cause mass displacement of communities and the lack of their social and political participation, such as the REDD (the first version of Reducing Emissions from Defloration and Degradation), the hydroelectric dams, the biofuel, and so on (Calañas \& Urbinati, 2020: p. 107). Therefore, climate justice also demands a focus on legal frameworks to address such indirect negative impacts 
on human rights, which have been well documented and highlighted by Civil Society Organizations (CSOs) and human rights scholars as negatives outcomes (Calañas \& Urbinati, 2020).

Therefore, the disproportionate incidence of the direct and indirect negative impacts of climate change has been considered a threat to the full enjoyment of human rights by people, connecting these rights with the pursuit of climate justice.

However, as the efforts grounded in these approaches have faltered to mitigate the direct and indirect negative impacts of climate change over the years, a growing number of scholars across law and the social sciences have become more interested in understanding how actors beyond national governments could help shape climate governance up to protect human rights (United Nations Framework Convention on Climate Change, 2015).

As a means that encompasses tools to enhance actions that guide constituents towards social justice before climate change, climate governance has been grounded on different governmental, economic and civil society actors' participation at all levels (Setzer \& Byrnes, 2020; Andonova, Betsill \& Bulkeley, 2009; Jordan, Huitema, Hildén et al., 2015).

It has become more manifest and relevant socially and politically due to the 2015 Paris Agreement, which recognized "the importance of the engagement of all levels of government and various actors" to address climate change (United Nations Framework Convention on Climate Change, 2015). This trend has been firmly established and highlighted the part played by subnational and no state actors in climate governance, including the courts (Peel \& Osofsky, 2020: p. 23).

Since then, another path to give effectiveness to climate governance has improved human rights protection before climate change: the climate litigation and the court's rules.

\section{Climate Governance through Law and Litigation Worldwide}

Regarding climate-related legislation and policies, the nation's climate actions are growing up in the world: between 1990 and 1999, had only 110 laws and significant policies, from 2010 to 2019, the flow of new laws had grown tenfold, to about 1100 laws and policies; in 2020, the total stock of climate change laws and policies worldwide stands at 1800 (Eskander, Fankhauser \& Setzer, 2020: p. 2).

Paired with the growth of climate-related laws and public policies initiatives is the increase of climate litigation worldwide. Although it couldn't be discerned whether or not developments in international law have influenced the number of climate cases, some scholars have observed the failure of the UN climate change conference in Copenhagen in 2009 (also known as COP15) boosted interest in climate litigation in some countries. Many of these cases that occurred hereafter have been put forward primarily by activists seeking the courts to challenge the National States' climate inaction. Then, following the Paris Agreement in 2015, there has been an increase in activity in some places worldwide, both in activism 
and new types of climate-related cases in the courts (Setzer \& Byrnes, 2020: p. 7). Thus, an expansion of climate governance tools has been taken place through the courts by climate litigation.

In recent years, the nation's judiciary has been called upon to express an opinion on applying rights and obligations related to climate change. This term climate litigation has been used to describe the set of judicial and administrative actions involving issues related to the reduction of greenhouse gas (GHG) emissions (mitigation), reducing vulnerability to the effects of climate change (adaptation), repair of damage suffered due to climate change (loss and damage) and the management of climate risks (risks). According to Peel \& Osofsky (2020: p. 24), it can be represented with concentric circles (Figure 1), which could express these legal instrumental notions of climate change litigation.

These legal instrumental notions have stretched the issues' legal interpretation and the courts' working in judging climate change cases. Thus, have been common judicial cases in which climate change could be just one of the many other claims in litigation, or even addressing a climate change issue as a clear motivation for, or a consequence of, to fill a lawsuit, but it is not present among the initial arguments taken to court (Setzer, Cunha \& Fabbri, 2019: p. 59; Peel \& Osofsky, 2020: p. 23).

Adopting a narrower definition of climate litigation, which focuses on judicial cases and targeted adjudications involving climate change, as a central legal

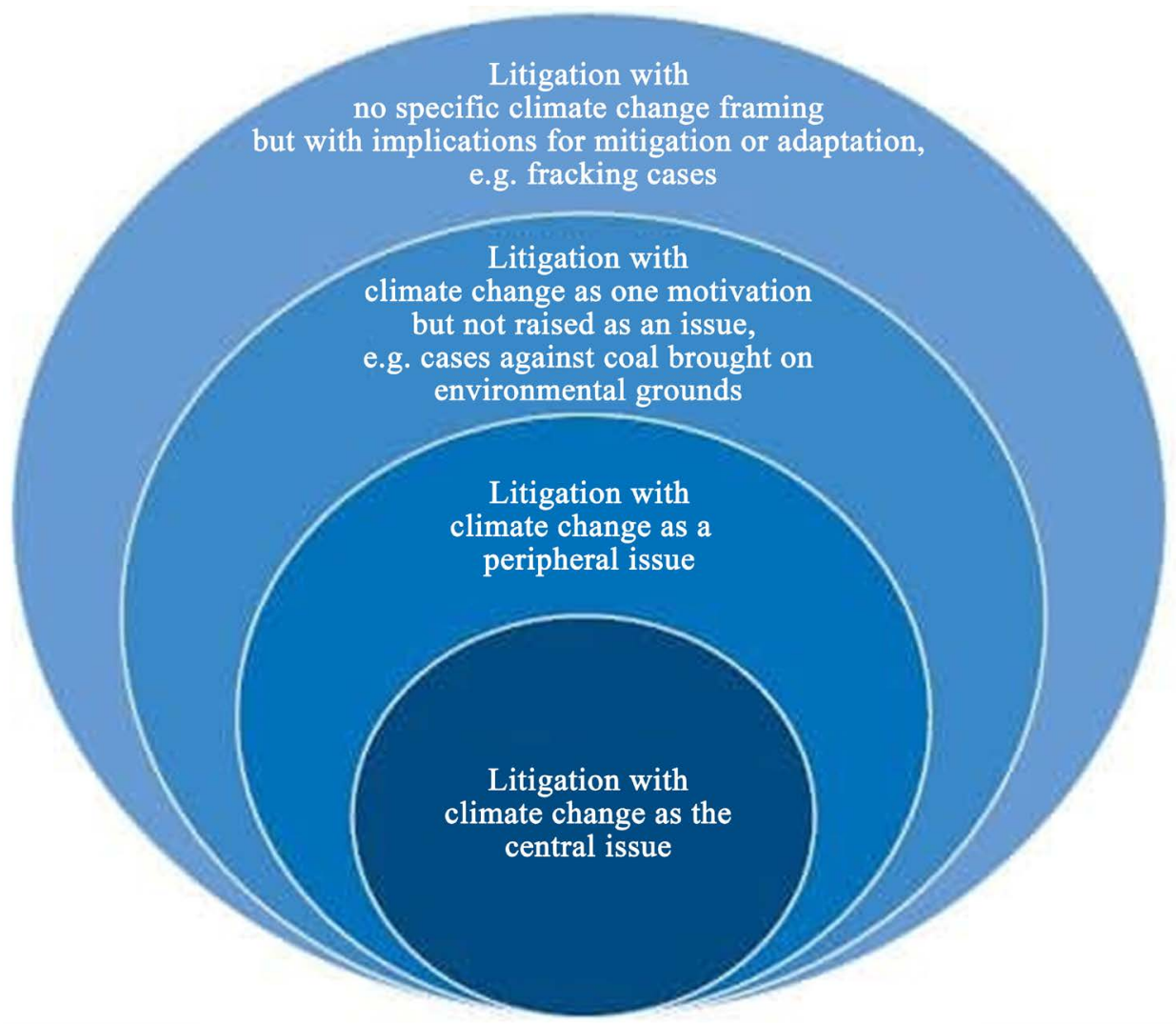

Figure 1. Legal notions climate litigation. 
argument or as a peripheral issue, presented to administrative entities and a few international bodies, such as the UN Human Rights Committee or Inter-American Court and Commission on Human Rights, the Grantham Research Institute on Climate Change and the Environment and the Centre for Climate Change Economics and Policy has identified in total 1587 cases of climate litigation as being brought between 1986 and the end of May 2020, mostly in the United States, 1213 cases. The other 374 cases occurred in 36 different countries and eight regional or international jurisdictions. The majority of climate litigation cases recorded since 1986 have arisen from the mid-2000s onwards, initially in industrialized countries, like the US, EU, and OECD member states. These data were produced mainly by the Sabin Center for Climate Change Law at Columbia University, with inputs from the Grantham Research Institute and others, according to Setzer \& Byrnes (2020: p. 10) in Figure 2.

These databases also contain 37 judicial cases of climate litigation in the Global South, of which 16 are in Asia, seven in Africa, and 14 in Latin America. More than half (21) of these judicial cases were brought in the five years between 2015 and 2019 (Setzer \& Byrnes, 2020; Wedy, 2017).

On November $8^{\text {th }}, 2020$, there are four pending climate change judicial cases litigation in Brazil, as can be seen in Figure 3, from Sabin Center for Climate Change Law (2020).

According to data from the Sabin Center for Climate Change Law (2020), only two of them relate climate change and indigenous rights. Despite that, the acting of Latin America and Brazil's indigenous people before climate change has shown a comprehensive expansion of this process of climate governance grounded in ethnical and political issues, a bona fide climate governance tool in today's Latin American multicultural societies.

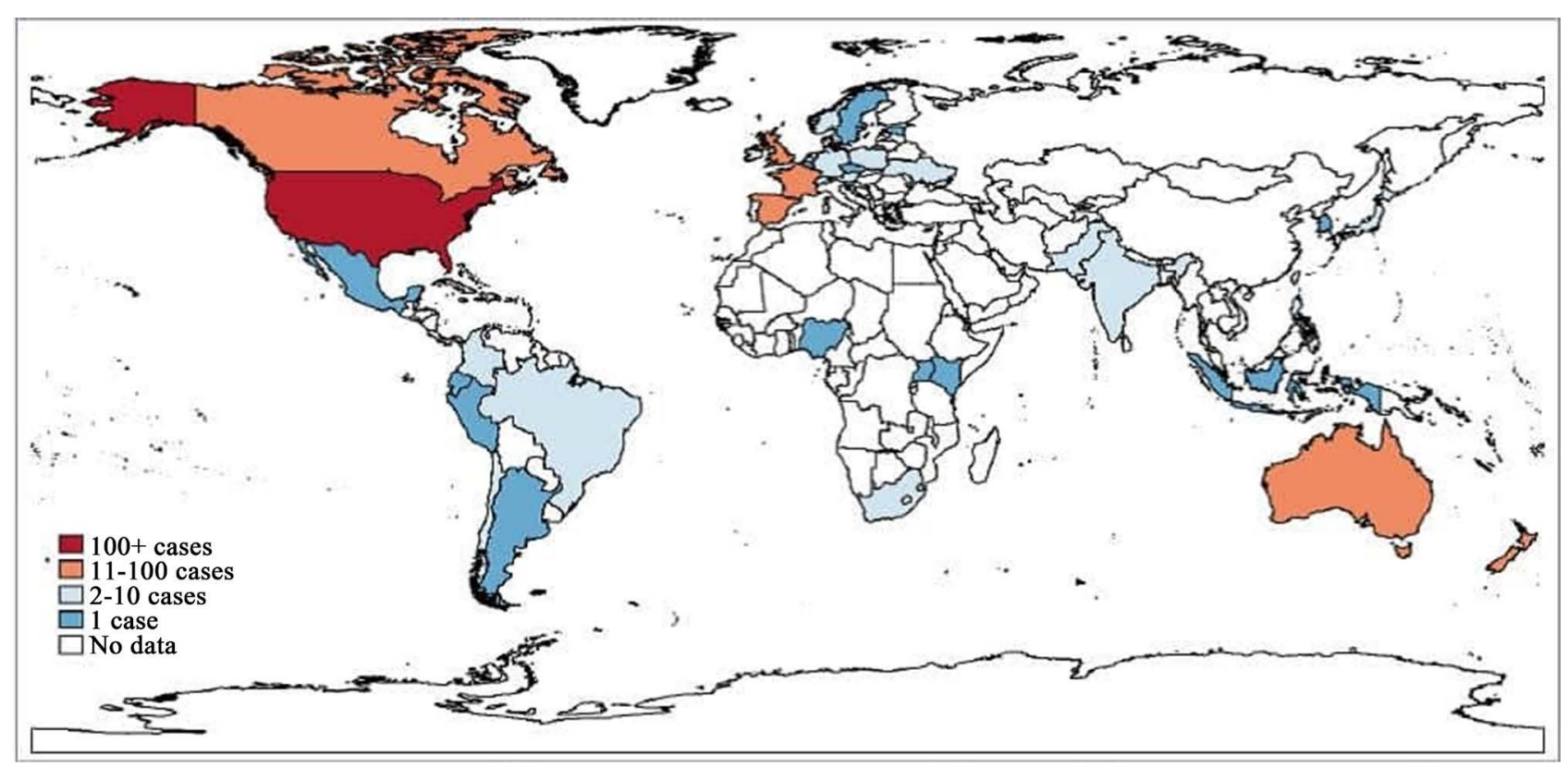

Figure 2. Climate litigation worldwide—number of cases at the end of May 2020. 


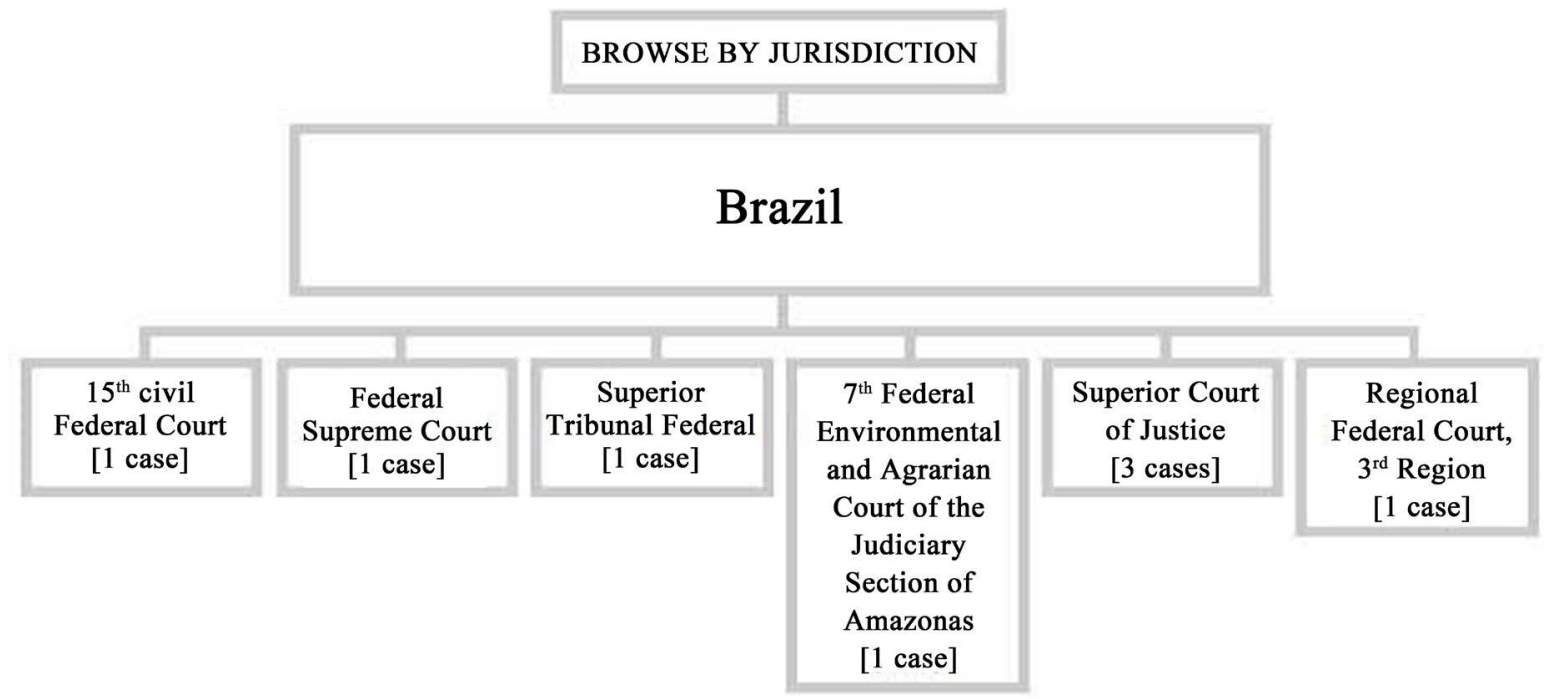

Figure 3. Climate litigation in Brazil-November 2020.

\section{Indigenous Ethnopolitic as Climate Governance Tool in Latin American and Brazil}

Although an already international recognition that their traditional life practices may offer solutions to combat climate change through reduction and reversing desertification, enhancing food system resilience, and playing a key role in understanding the climate processes and their impacts on the adaptation strategy (United Nations Framework Convention On Climate Change, 2015; Intergovernmental Panel on Climate Change, 2020), indigenous peoples are also one of the most vulnerable social groups to climate change impacts itself and inappropriate humans solutions to climate change and their development initiatives (Balawag et al., 2020: p. 28; Ribeiro, 2020, p. 53).

In this sense, if on the one hand, their closest way of life to nature gives them more knowledge about the waters sources, soil, plants, and animals that make them understand when changes are happening in the surrounding environment, by the other hand, they bear disproportionately the brunt of climate change (Balawag et al., 2020: p. 29).

The direct negative climate change's impacts on their collective human rights have taken place as their activity of planting, growing, and harvesting and the production cycle have affected the availability of food, as their traditional way to obtain food such as hunting, fishing, and gathering were also negatively affected by climate change. Hence, in a comprehensive view, these impacts on indigenous' human rights have been taking place as their culture and basis of social identity and unity have been suffered (Balawag et al., 2020: pp. 29-30).

The indirect negative impacts on their human rights have been taking place with solutions to reduce the effects of climate change, adopting the called lesscarbon alternatives, such as biofuels, hydroelectric power dams, or even by indigenous peoples' adopting of the first version of Reducing Emissions from Deforestation and Degradation (REDD). These solutions have also created or in- 
creased risks and vulnerabilities to indigenous peoples by threatening their collective human rights as the existential-ecological minimum of indigenous communities, the self-determination and autonomy, and the right to consultation and political participation (Balawag et al., 2020).

Therefore, it would require an expansive and comprehensive formulation of climate governance toward indigenous human rights beyond litigation and national policies. This formulation would help understand and improve the political empowerment of those most vulnerable to climate change and their role in climate governance to achieve broader and efficient climate justice.

\subsection{Climate Justice from Indigenous' Ethnopolitical}

As a starting point, it would initially bear in mind the human rights-based approach (HRBA), and the asserted "common but differentiated responsibility" (CBDR) principle, both associated with climate justice.

Grounded on these approaches, indigenous people's claims before the climate changes in Latin America and Brazil have taken ethnopolitics paths. In this way, ethnicity and its inherent cultural aspects are used for political purposes and goals, particularly seeking out climate justice due to climate change's adverse effects on their collective human rights.

Lest we overlook ethnopolitics' influence in modern states and societies' events and histories, it's necessary to bear in mind that ethnic identity still contributes to shaping political issues. From the basis for the nineteenth-century development of national identities to the claims for self-determination, the ethnonationalism "at the heart of the implosion of the Soviet Union and the explosion of Yugoslavia," and to negatively reacting to the growing presence of "others" in multicultural societies (Rudolph, 2019: p. 150), ethnopolitic shows up in all political arena's levels.

When it comes to indigenous peoples, the concept of ethnopolitics presupposes a recent step forward on anthropologic studies accomplished by poststructuralist critics, such as Michael Foucault, James Scott, and Nicos Poulantzas, which expanded the concept of politics that have been pluralized definitively, beyond the state or hegemonic societies' matters (Ferreira, 2017: p. 195). This approach operated on expanding political ideas to encompass peripheral societies' forms and systems, including traditional and stateless societies ones.

Thus, ethnopolitic is a concept that could specify the political activity of ethnic groups or interethnic systems that contains marks of its historical experience, culture, social organization, and its life's base material-ecological (Ferreira, 2017: p. 198). This ethnic politicization is noteworthy among traditional and stateless societies and has pointed to a worldwide indigenous' political protagonist at all climate governance levels.

\subsection{Expansive and Comprehensive Climate Governance Tools from Indigenous' Ethnopolitical}

An indigenous' ethnopolitical movement which has shaped expansive and com- 
prehensive climate governance tools at an international political level took place at the Conference of the Parties (COP 4), from 2 to 13 November 1998, in Buenos Aires, culminating in creating the first International Indigenous Forum on Climate Change (IIPFCC). This political arena was designed to articulate indigenous organizations during COPs to construct positions and strategy actions. Indigenous intervention in COPs was marked by press conferences and sideevents, which brought visibility to a broader audience, and speeches in specific plenary sessions opened to civil society contributions. At the same time, indigenous representatives organized several private meetings with government and non-government representatives, improving their capacities of articulation and presentation of indigenous organizations' agenda (Mesquita, 2018: p. 37).

A relevant outcome of this articulation was the denunciation of indigenous peoples' climate injustice due to a globally celebrated solution mechanism for mitigating climate change: the reducing emissions from deforestation and forest degradation in developing countries, as known as REDD. This mechanism had been discussed since 2005 at COPs as a way to encourage developing countries to preserve their forest areas financially. From 2005 to 2010, the initial REDD proposal was under discussion at an international level. Regarding this mechanism and its negatives effects on indigenous people, the Coordination of the Indigenous Organizations of the Amazon Basin (COICA), established by Latin American indigenous representatives from Peru, Guyana, Ecuador, Suriname, French Guiana, Venezuela, Bolivia, and Brazil, issued the "Carta de Cuiaba sobre el cambio climático y los pueblos indígenas," presenting 21 recommendations for COP 14.

This document highlighted, for example, that the REDD could not ignore the autonomy of indigenous peoples over their territories. As a result, at COP 16, guidelines are established to reduce the risks of negative REDD impacts, known as the Cancun Agreement. Therefore, Decision 1/CP.16 recognizes contributing to mitigating climate change actions that include those who, like indigenous peoples, conserve forest areas. The inclusion of these actions in REDD resulted in the addition of the " + " symbol to the acronym, referred to hereafter as REDD + , improving the effective participation of local peoples and communities in taking such actions (Mesquita, 2018: p. 42; Anderson, 2009; Coordinadora de las Organizaciones Indígenas de la Cuenca Amazónica, 2014).

Another remarkable indigenous' ethnopolitical movement that has also contributed to enhancing expansive and comprehensive climate governance took place at the UN Climate Change Conference COP 25 (2 - 13 December 2019). This conference aimed to take forward steps in the UN climate change process to operationalize the Paris Climate Change Agreement (United Nations Climate Change, 2019). During the parallel event "Threats to the Amazon: fires, infrastructure, and deforestation," representatives of indigenous organizations of the Amazon Basin (Coordinadora de las Organizaciones Indígenas de la Cuenca Amazónica) demanded respect not only for their fundamental rights but also for effective participation in climate agreement according to their cultural and tradi- 
tional issues (Coordinadora de las Organizaciones Indígenas de la Cuenca Amazónica, 2019). Meeting this demand was included in the main products of the conference, the Decisions adopted by the Conference of the Parties. According to some of these decisions, the parties agreed to act to invite indigenous peoples to collaborate and co-host a dialogue to discuss advancing the leadership and "highlighting ways of enhancing their effective participation in climate policy and action," and to deploy technological solutions to address climate change by promoting local, "indigenous and traditional knowledge and practices in different sectors." (United Nations, 2019).

Besides, the insertion of Latin American indigenous people's claims in climate standards, laws, and policies by the nationals states has taken place not only due to states' compliance with the Paris Agreement but also to indigenous' political protagonism at local, national, and regional arenas (Ribeiro, 2020). This context has shaped expansive and comprehensive climate governance legal tools based on ethnopolitical issues and activities among all public spheres levels. It can be deduced when analyzing the National Policy for Colombia Climate Change (2017), the National Policy for Adaptation to Costa Rica's Climate Change 20182030, the National Policy for Mitigation and Adaptation to Climate Change in Nicaragua (2019), and Uruguay's National Climate Change Policy (2017), and the nationals climate laws of Argentina (2019), Colombia (2018), Mexico (2018), Paraguay (2017) and Peru (2018), according to Ribeiro (2020: pp. 105-121).

These nationals laws, plans, and policies can gather some clues about the Latin American National States' strategies to combat climate change and meet the indigenous people's claims as well: the State's recognition of indigenous people as one of the most vulnerable social group to climate change impacts; the State's recognition of the indigenous traditional knowledge and ancestral practices as an adaptation and mitigation strategies; the implementation of the principle of participation and inclusion in national board or commission of public policies about climate change; and the intercultural approach, valuing and incorporating diverse cultural visions, ancestral knowledge and concepts of the well-being of indigenous peoples in the preservation and sustainable use of natural resources and managing climate change (Ribeiro, 2020).

In Brazil, this movement has been strengthening since the consolidation of Indigenous ethnopolitical articulations from the 1970s and 1980s, with remarkable outcomes on the 1988 constituent process. An occasion on which, besides the ethno relations that evolved regional languages, regional economic conditions through time, the ethnopolitical representation contributed to redefined the Brazilian nations' constitutional order (Deus, 2020; Ferreira, 2017), as Rudolph (2019) asserted about this movement around the world.

Brazilian indigenous people have also mobilized ethnopolitically to create parallels paths to face the adverse effects of climate change, like the settlement of the Indigenous Climate Change Committee (ICCC) to monitor and participate in public debates related to climate change, on a national and international scale and promote dialogue between indigenous peoples and the government to in- 
crease indigenous incidence on the topic; participation in the creation of the Climate Indigenous Alert application, that sends information on hot spots, deforestation, and drought risk to the Indigenous Lands of the Brazilian Amazon; and many local meetings to discuss and outline goals and plans to prevent the locals' negative consequences of climate changes (Ribeiro, 2020: p. 61; Instituto de Pesquisa Ambiental da Amazônia, 2017; Conselho Indígena de Roraima, 2019).

\section{Research Findings' Analysis}

All these movements represent an extensive and comprehensive formulation of climate governance from indigenous people's claims before climate change.

From this approach, beyond the increased's trends of national's laws, policies, and litigation before national and international courts, the indigenous people's activism and ethnopolitical protagonism related to human rights before climate changes in Latin American has led to an expansive and comprehensive formulation of climate governance by meeting the indigenous ethnic groups' specific demands and embracing expansive political participation and comprehensive cultural issues.

This formulation is expansive insofar goes beyond state and hegemonic society's climate governance tools and comprises the fostering, creating, and maintaining political protagonism arenas grounded in ethnics and its composite cultural aspects related to climate changes' causes and effects.

This formulation is comprehensive because it embraces the specific demands of those who, due to their traditional way of life, depend closely on a balanced ecological system and usually bear a disproportionate burden from the negative impacts of climate changes. It is also comprehensive by open to the public discussing those impacts caused by states and hegemonic societies' mechanisms to face climate change, disregarding the specificities of the diverse ethnicities and indigenous cultures involved.

\section{Conclusion}

Most of the related disproportionate climate changes' adverse effects among different peoples worldwide have highlighted a close relationship between human rights and climate justice. After that, civil society and social movements have been engaging efforts at international, national, and sub-national's levels to address their claims related to climate changes' harmful effects.

Taking into account the human rights-based approach (HRBA) toward the equity and justice aspects inherent to both climate changes' causes and effects and the two broader critical issues associated with the "common but differentiated responsibility" (CBDR) principle, right scholars and practitioners, Civil Society Organizations (CSOs) and activists have been seeking the courts to challenge climate inaction.

These climate governance's standards have been also pushed forward by indi- 
genous people movements which have politically empowered them in Latin America through parallels paths to face the negative effects of climate change. These paths include political arenas to monitor and participate in debates and policies related to climate change, promoting dialogue with the government, participation in the creation of technologies, and promoting meetings to discuss and outline goals and plans related to direct and indirect negatives consequences of climate changes.

These findings indicate that besides the increase's trends of national's laws, policies, and litigation before national and international courts, the indigenous people's ethnopolitical protagonism related to their claims on the collective human rights before climate changes in Latin American has updated the formulation of climate governance by an expansive and comprehensive approach.

Expansive because it goes beyond state and hegemonic society's climate governance tools due to political protagonism arenas grounded in ethnics and its composite cultural aspects to face climate changes' causes and effects. Comprehensive because it adopts a multicultural perspective of adopting mechanism to address climate change impacts, which concerns the traditional way of life of the diverse ethnicities and cultures vitally dependent on a balanced ecological system.

\section{Conflicts of Interest}

The authors declare no conflicts of interest regarding the publication of this paper.

\section{References}

Anderson, N. (2009). REDDy or Not? The Effects on Indigenous Peoples in Brazil of a Global Mechanism for Reducing Emissions from Deforestation and Degradation. Journal of Sustainable Development, 2, 18. https://doi.org/10.5539/jsd.v2n3p18 http://41.73.194.134/xmlui/bitstream/handle/123456789/167/reddy\%20or\%20not.pdf?s equence $=1$

Andonova, L. B., Betsill, M. M., \& Bulkeley, H. (2009). Transnational Climate Governance. Global Environmental Politics, 9, 52-73.

https://doi.org/10.1162/glep.2009.9.2.52

Balawag, G., Biangalen-Magata, H., Bugtong-Biano, \& Chavez, R. (2020). Climate Justice and Indigenous Peoples. In L. Urbinati (Ed.), Climate Justice: Navigating the Discourse (pp. 28-38). FORUM-ASIA Working Paper Series: Asian Perspectives on International Human Rights Landscapes Number 8, Bangkok: Kornkanok Printing.

Calañas, D., \& Urbinati, L. (2020). A Human Rights-Based Approach to Climate Change and Climate Justice. In L. Urbinati (Ed.), Climate Justice: Navigating the Discourse (pp. 1-11). FORUM-ASIA Working Paper Series: Asian Perspectives on International Human Rights Landscapes Number 8, Bangkok: Kornkanok Printing.

Conselho Indígena de Roraima (2019). Povos indígenas da Terra Indígena Raimundão discutem sobre mudanças climáticas.

https://cir.org.br/site/2019/11/05/povos-indigenas-da-terra-indigena-raimundao-discu tem-sobre-mudancas-climaticas

Coordinadora de las Organizaciones Indígenas de la Cuenca Amazónica (2014). REDD+ 
INDÍGENA AMAZÓNICO-RIA: Gestión Holística de Territorio de Vida Plena. http://www.coica.org.ec/images/pdf/REDD+RIA.pdf

Coordinadora de las Organizaciones Indígenas de la Cuenca Amazónica (2019). Pueblos indígenas demandan el respeto a sus derechos fundamentales y participación efectiva en los acuerdos climáticos.

https://coica.org.ec/\%ef\%bb\%bfpueblos-indigenas-demandan-el-respeto-a-sus-derecho s-fundamentales-y-participacion-efectiva-en-los-acuerdos-climaticos

Deus, J. A. S. (2020). New Territorialities and Collective Ethnic Identities in the Brazilian Amazon Frontier, Rondonia State: Surui Paiter, Arara, and Gavião Indigenous Communities' Land Claims and Alternative Cultural Landscapes. In W. Leal Filho, V. King, \& I. Borges de Lima (Eds.), Indigenous Amazonia, Regional Development and Territorial Dynamics. The Latin American Studies Book Series (pp. 181-194). Cham: Springer. https://doi.org/10.1007/978-3-030-29153-2 7

Eskander, S., Fankhauser, S., \& Setzer, J. (2020). Global Lessons from Climate Change Legislation and Litigation. In Annual NBER Environmental and Energy Policy and the Economy Conference (p. 2). Washington DC: University of Chicago Press.

https://www.nber.org/chapters/c14503

https://doi.org/10.3386/w27365

Expert Group on Climate Obligations of Enterprises (2018). Principles on Climate Obligations of Enterprises.

https://climateprinciplesforenterprises.files.wordpress.com/2017/12/enterprisesprincipl eswebpdf.pdf

Expert Group on Global Climate Obligations (2015). Oslo Principle on Global Climate Change Obligations. The Hague: Eleven International Publishing. https://climateprinciplesforenterprises.files.wordpress.com/2017/12/osloprinciplesweb pdf.pdf

Ferreira, A. C. (2017). Etnopolitica e Estado: Centralizacao e descentralizacao no movimento indígena brasileiro. Anuário Antropologico, 42, 195-226.

https://doi.org/10.4000/aa.1709

Instituto de Pesquisa Ambiental da Amazônia (2017). Povos indígenas protagonizam o debate sobre mudanças climáticas. Notícias.

https://ipam.org.br/povos-indigenas-protagonizam-o-debate-sobre-mudancas-climaticas

Intergovernmental Panel on Climate Change (2020). Climate Change and Land. An IPCC Special Report on Climate Change, Desertification, Land Degradation, Sustainable Land Management, Food Security, and Greenhouse Gas Fluxes in Terrestrial Ecosystems. Summary for Policymakers. https://www.ipcc.ch/site/assets/uploads/sites/4/2020/02/SPM Updated-Jan20.pdf

Jordan, A., Huitema, D., Hildén, M. et al. (2015). Emergence of Polycentric Climate Governance and Its Future Prospects. Nature Climate Change, 5, 977-982.

https://doi.org/10.1038/nclimate2725

Mesquita, I. (2018). Fazer-se ouvir, fazer-se entender-atuação política interétnica da COICA nas negociações sobre o clima com a proposta de REDD+ Indígena Amazônico. Revista de Estudos em Relações Interétnicas, 21, 27-49.

https://periodicos.unb.br/index.php/interethnica/article/view/10589

https://doi.org/10.26512/interethnica.v21i1.10589

OHCHR (2020). Applying a Human Rights Based Approach to Climate Change Negotiations, Policies, and Measures.

https://www.ohchr.org/documents/issues/climatechange/infonotehrba.pdf

Olawuyi, D. (2015). Advancing Climate Justice in International Law: An Evaluation of the 
United Nations Human Rights Based Approach. Florida A \& M University Law Review, $11,103$.

https://commons.law.famu.edu/cgi/viewcontent.cgi? article=1145\&context=famulawr eview

Peel, J., \& Osofsky, H. M. (2020). Climate Change Litigation. Annual Review of Law and Social Science, 16, 21-38. https://doi.org/10.1146/annurev-lawsocsci-022420-122936 https://www.annualreviews.org/doi/pdf/10.1146/annurev-lawsocsci-022420-122936

Ribeiro, H. M. (2020). As mulheres indígenas na regulação do clima da América Latina: Caminhos para um direito ecológico. Boa Vista: Editora da UFRR.

Rudolph, J. R. (2019). The Significance of Ethno-Politics in Modern States and Society. In S. Ratuva (Ed.), The Palgrave Handbook of Ethnicity (pp. 149-167). Palgrave Macmillan. https://doi.org/10.1007/978-981-13-2898-5 13

Sabin Center for Climate Change Law (2020). Climate Change Litigation Databases. NonU.S. Climate Change Litigation. http://climatecasechart.com/non-us-jurisdiction/brazil

Setzer, J. (2020). Global Lessons from Climate Change Legislation and Litigation. In Annual NBER Environmental and Energy Policy and the Economy Conference (p. 2). Washington DC: University of Chicago Press. https://www.nber.org/chapters/c14503 https://doi.org/10.1086/711306

Setzer, J., \& Byrnes, R. (2020). Global Trends in Climate Change Litigation: 2020 Snapshot-Policy Report July 2020.

https://www.lse.ac.uk/granthaminstitute/publication/global-trends-in-climate-change-1 itigation-2020-snapshot

Setzer, J., Cunha, K., \& Fabbri, A. B. (2019). Panorama da litingância climática no Brasil e no mundo. In J. Setzer, K. Cunha, \& A. B. Fabbri (Eds.), Litigância Climática: Novas fronteiras para o direito ambiental no Brasil (pp. 59-86). São Paulo: Thomson Reuters.

Sustainable Development Goals (2020). Goal 13: Take Urgent Action to Combat Climate Change and Its Impacts. https://www.un.org/sustainabledevelopment/climate-change

United Nations (2019). Report of the Conference of the Parties on Its Twenty-Fifth Session, Held in Madrid from 2 to 15 December 2019. https://unfccc.int/sites/default/files/resource/cp2019 13a01E.pdf

United Nations Climate Change (2019). About the UN Climate Change ConferenceDecember 2019.

https://unfccc.int/about-the-un-climate-change-conference-december-2019

United Nations Framework Convention on Climate Change (1997). Kyoto Protocol to the United Nations Framework Convention on Climate Change. https://unfccc.int/sites/default/files/resource/docs/cop3/107a01.pdf

United Nations Framework Convention on Climate Change (2015). The Paris Agreements.

https://unfccc.int/files/essential background/convention/application/pdf/english paris agreement.pdf

United Nations Human Rights Council (2008). Resolution 7/23-Human Rights and Climate Change.

https://ap.ohchr.org/documents/E/HRC/resolutions/A HRC RES 7 23.pdf

United Nations Human Rights Council (2009). Annual Reports of the Human Rights Council. New York: United Nations. https://undocs.org/A/64/53

United Nations Human Rights Council (2016). Report on Human Rights and Climate Change. A/HRC/31/52. Report of the Special Rapporteur on the Issue of Human Rights Obligations Relating to the Enjoyment of a Safe, Clean, Healthy and Sustainable Environment. 
https://www.ohchr.org/ layouts/15/WopiFrame.aspx?sourcedoc=/Documents/Issues/E nvironment/A.HRC.31.52 AEV.docx\&action=default\&DefaultItemOpen $=1$

United Nations. (1992). United Nations Conference on Environment and Development Declaration.

https://www.un.org/en/development/desa/population/migration/generalassembly/docs /globalcompact/A CONF.151 26 Vol.I Declaration.pdf

Wedy, G. (2017). Climate Legislation and Litigation in Brazil. Sabin Center for Climate Change Law, New York: Columbia Law School.

https://climate.law.columbia.edu/sites/default/files/content/Wedy-2017-10-Climate-Le gislation-and-Litigation-in-Brazil.pdf

https://doi.org/10.2139/ssrn.3052226 